уДК 61:007

\title{
ІНФОРМАЦІЙНА СИСТЕМА РЕЄСТРУ ХВОРИХ НА МУКОВІСЦИДОЗ
}

\author{
Н. Г. Горовенко ${ }^{2}$, В. З. Стецюк ${ }^{1}$, Т. П. Іванова ${ }^{3}$, \\ А. Й. Савицький ${ }^{1}$, Ю. О. Луговський ${ }^{1}$ \\ Конструкторське бюро інформаційних систем національного технічного університету \\ України «Київський політехнічний інститут» 1 \\ Національна медична академія післядипломної освіти імені П. Л. Шупика² \\ Національна дитяча спеціалізована лікарня «ОХМАТДИТ»з
}

\begin{abstract}
Показано складність організаційної роботи щодо реєстрації, ведення медичної документації хворих на муковісцидоз і нагляду за ними протягом житя. Запропоновано вирішення цих труднощів за допомогою впровадження інформаційної системи, особливістю якої $є$ виведення результатів обробки даних у зручному для читання форматі, створення звітів відповідно до європейських шаблонів, а також двомовний українсько-російський інтерфейс із можливістю його розвитку шляхом додавання будь-яких інших мов.
\end{abstract}

Ключові слова: інформаційна система, муковісцидоз, реєстр хворих, документообіг.

\section{ИНФОРМАЦИОННАЯ СИСТЕМА РЕЕСТРА БОЛЬНЫХ МУКОВИСЦИДОЗОМ}

Н. Г. Горовенко ${ }^{2}$, В. З. Стецюк', Т. П. Иванова ${ }^{3}$, А. Й. Савицкий ${ }^{1}$, Ю. А. Луговский ${ }^{1}$

Конструкторское бюро информационных систем национального технического университета Украины “Киевский политехнический институт»'

Национальная медицинская академия последипломного образования имени П. Л. Шупика Национальная детская специализированная больница "ОХМАТДЕТ»з

Показано сложность организационной работы по регистрации, ведению медицинской документации больных муковисцидозом и наблюдению за ними в течение жизни. Предложено решение этих сложностей при помощи внедрения информационной системы, особенностью которой является выведение результатов обработки данных в удобном для чтения формате, создание отчетов в соответствии с европейскими шаблонами, а также двуязычный украинско-русский интерфейс с возможностью развития путем добавления каких-либо других языков.

Ключевые слова: информационная система, муковисцидоз, реестр больных, документооборот.

\section{INFORMATION SYSTEM FOR REGISTRY OF PATIENTS WITH CYSTIC FIBROSIS}

\author{
N. H. Horovenko², V. Z. Stetsyuk', T. P. Ivanova ${ }^{3}$, \\ A. Y. Savytskyi', Yu. O. Luhovskyi' \\ Design Bureau of Information Systems of National Technical University of Ukraine «Kyiv \\ Polytechnic Institute'" \\ National Medical Academy of Postgraduate Education ${ }^{2}$ by P. L. Shupyk \\ National Children's Specialized Hospital «OKHMATDYT» ${ }^{3}$

\begin{abstract}
The complexity of organizational work on registration, maintenance of medical records of patients with cystic fibrosis and supervision for life is shown. This information system is promising because can store and process all the necessary information, make statistical reporting forms in accordance with European standards, it has a bilingual interface (Ukrainian, Russian), but if it necessary can be added the English or any other.
\end{abstract}

Key words: information system, cystic fibrosis, register of patients, workflow.

(с) Н. Г. Горовенко, В. 3. Стещюк, Т. П. Іванова, А. Й. Савищький, Ю. О. Луговський 
Вступ. Сьогодні відомо багато різноманітних спадкових недуг, однією із них $є$ муковісцидоз. Зазначимо, що муковісцидоз є найпоширенішим моногенним спадковим захворюванням із аутосомно-рецесивним типом успадкування. Основні його прояви: хронічний обструктивний процес у дихальних шляхах, що супроводжується рекурентною бактеріальною інфекцією, порушення травної системи з недостатністю екзокринної функції підшлунковоїзалози, підвищений вміст електролітів у потовій рідині та обструктивна азооспермія у чоловіків, що обумовлена вродженою агенезією сім'явиносних проток.

В Україні частота муковісцидозу становить 1 на 2300 новонароджених, тобто кожний рік народжується 250-300 хворих дітей. У світі щороку реєструють більше 45000 випадків муковісцидозу в дітей. Частота носіїв гена муковісцидозу - 3-4\%. Всього на земній кулі близько 275 млн людей-носіӥв цього гену.

Діагноз грунтується на клінічних даних, а також на результатах біохімічного обстеження. Лікування хворих на муковісцидоз триває впродовж усього життя й особлива увага звертається на дієто-, ферменто-, i вітамінотерапію.

Особливість роботи лікаря з цим захворюванням визначається специфікою встановлення діагнозу та застосування необхідних методів контролю за станом здоров'я хворого протягом життя. Іншиими важливими факторами для лікарів, які працюють 3 хворими на муковісцидоз, є комунікація між відділеннями метаболічних центрів різних лікарень України, ведення статистичних форм і створення реєстру хворих.

Мета дослідження - спростити та підвищити продуктивність роботи лікарів із пацієнтами, хворими на муковісцидоз.

Матеріал і методи дослідження. Об'єкт дослідження - інформаційні потоки медичної документації та організаційні заходи метаболічного центру. Предмет дослідження: форми медичної документації, обов'язкові форми статистичної звітності, послідовність заповнення документів тощо.

Для розроблення програмного продукту, а саме, його інтерфейсної частини, логіки обчислення, за-

\section{Література}

1. Павловская Т. А. СН. Программирование на языке высокого уровня : учеб. для вузов / Т. А. Павловская. - СПб. : Питер, 2007.-432с. : ил. - ISBN 978-5-91180-174-8

2. Visual C\# 2008 : базовый курс / К. Уотсон, К. Нейгел, Д. Рид [и др.] ; пер. с англ. Я. П. Волковой, Д. Я. Иваненко, Ю. И. Корниенко [и др.] ; зав. ред. С. Н. Тригуб.-М. ООО собів комунікацій із сервером бази даних (БЛ), використовували середовище розробки «Visual Studio» та мову програмування С\#. Ці засоби дозволили створити програму з дружнім інтерфейсом для лікаря. Для збереження інформації встановлено сервер бази даних MS SQL. Для взаємодії сервера БД із програмним продуктом використовували технологію ADO .NET.

Результати та їх обговорення. Створений програмний продукт дозволяє вирішувати такі завдання: повне збереження інформації в базі даних про хворого, графічне відображення стану здоров'я пацієнта, що визначається за його виміряними значеннями ваги, зросту та віку відносно нормативних значень, проведення пошуку пацієнтів за вказаними параметрами, формування шифрованого файла з даними пацієнта, занесення інформації про пацієнта в базу даних із файла, створеного цією ж програмою, що дозволяє обмінюватись інформацією між лікарнями різних регіонів, створення та заповнення документів iз розширенням (*.doc) за вказаним шаблоном та багато інших підзавдань.

Цікавою особливістю, що значно полегшує і дозволяє контролювати роботу лікарів, є система повідомлень про «поточний стан пацієнтів)». Тобто програма сама «підказує) лікарю, де і якої інформації не вистачає чи які дані не надійшли, наприклад, для встановлення діагнозу, або повідомляе, яку маніпуляцію слід зробити певному пацієнтові.

Іншим важливим завданням системи є формування необхідної статистики та ресстру хворих. Ця програма виконуватиме їх і представлятиме інформацію у вигляді, що відповідає європейським стандартам.

Висновок. Програмний продукт є досить перспективним, адже він містить засоби вводу всієі необхідної інформації про паціснта, реалізує методи обробки даних і виведення ї̈ результатів у зручному для читання форматі. Формує звіти та реєстр хворих відповідно до європейських стандартів і має двомовний українсько-російський інтерфейс із можливістю розвивати його, додаючи будь-які інші мови.

«И. Д. Вильямс», 2009. - 1216 с. - Парал. тит. англ. - ISBN 978-5-8459-1532-0

3. Ицик Б. Microsoft Sql Server 2008. Основы T-SQL / Б. Ищик; пер. с англ. Т. Коротяевой ; глав. ред. Е. Кондукова ; зав. ред. Г. Добин. - СПб. : БХВ-Петербург, 2009. -432с. : ил. - ISBN 978-5-9775-0220-7. 